\title{
Spatial Distribution and Contamination of Heavy Metals in Street Dust from Hamedan, Iran
}

\author{
Maryam Hemati ${ }^{1}$ and Ghasem Rahimi ${ }^{2 *}$ \\ ${ }^{1}$ Graduated Msc. Soil Science Department, Faculty of Agriculture, Bu-Ali Sina University, Hamedan, Iran
}

${ }^{2}$ Soil Science Department, Faculty of Agriculture, Bu-Ali Sina University, Hamedan, Iran

*Corresponding author: Ghasem Rahimi, Soil Science Department, Faculty of Agriculture, Bu-Ali Sina University, Hamedan, Iran

\begin{tabular}{|c|c|}
\hline ARTICLE INFO & ABSTRACT \\
\hline Received: 㸷 August 18, 2020 & In the Anthropocene, researchers are to pay special attention to heavy metal pollu- \\
\hline Published: September 02, 2020 & $\begin{array}{l}\text { tion associated with urban dust particles, amid overwhelming concerns that heavy met- } \\
\text { als might exert considerable impacts on ecosystem and human health. In this research, }\end{array}$ \\
\hline $\begin{array}{l}\text { Citation: Maryam Hemati, Ghasem Rahimi } \\
\text { Spatial Distribution and Contamination of } \\
\text { Heavy Metals in Street Dust from Hamed- } \\
\text { an, Iran. Biomed J Sci \& Tech Res 30(1)- } \\
\text { 2020. BJSTR. MS.ID.004882. }\end{array}$ & $\begin{array}{l}\text { low traffic streets, parks, residential, and industrial areas of Hamedan, Iran, as well as } \\
\text { background city soils. The samples were analyzed for } \mathrm{Zn}, \mathrm{Cu}, \mathrm{Pb}, \mathrm{Mn}, \mathrm{Cr} \text { and } \mathrm{Co} \text {, using the } \\
\text { atomic absorption spectrophotometric technique and ICP MS. Data showed that mean } \\
\text { values for } \mathrm{Zn}, \mathrm{Cu}, \mathrm{Pb}, \mathrm{Mn}, \mathrm{Cr} \text {, and Co in the dust samples were } 189.9,63.8,63.0,378.5 \text {, } \\
\text { 33.0, and } 19.8 \mathrm{mg} \mathrm{Kg}^{-1} \text {, respectively. The street dust samples were found to contain signif- } \\
\text { icant levels of } \mathrm{Cu} \text {, compared to the background; however, their geo-accumulation indices }\end{array}$ \\
\hline $\begin{array}{l}\text { Keywords: Contamination; Spatial Distri- } \\
\text { bution; Street Dust; Hamedan; Heavy Met- } \\
\text { al; Iran }\end{array}$ & $\begin{array}{l}\left(\mathrm{I}_{\text {geo }}\right) \text { suggested them to be uncontaminated with } \mathrm{Zn}, \mathrm{Pb}, \mathrm{Mn}, \mathrm{Cr} \text { and } \mathrm{Co} \text {, and moderately } \\
\text { contaminated with } \mathrm{Cu} \text {. The Igeo values were in the following order: } \mathrm{Cu}>\mathrm{Pb}, \mathrm{Zn}>\mathrm{Mn}>\mathrm{Cr}>- \\
\mathrm{Co} \text {. The enrichment factor }(\mathrm{EF} \text { ) was estimated for all studied heavy metals by using } \mathrm{Mn} \text { as } \\
\text { the reference element. Except from } \mathrm{Cu} \text {, the mean values of } \mathrm{EF} \text { were less than } 2 \text { for other } \\
\text { heavy metals. The values of } \mathrm{EF} \text { were in the following order: } \mathrm{Cu}>\mathrm{Zn}, \mathrm{Pb}>\mathrm{Cr} \text { and } \mathrm{Co} \text {. The } \\
\text { pollution index (PI) suggested that dust particles were uncontaminated with } \mathrm{Mn}, \mathrm{Cr} \text {, and } \\
\mathrm{Co} \text {; moderately contaminated with } \mathrm{Zn} \text { and } \mathrm{Pb} \text {; but contaminated with } \mathrm{Cu} \text {. The values of } \\
\text { PI were in the following order: } \mathrm{Cu}>\mathrm{Zn}>\mathrm{Pb}>\mathrm{Mn}>\mathrm{Cr} \text { and } \mathrm{Co} \text {. }\end{array}$ \\
\hline
\end{tabular}

\section{Introduction}

In recent decades, characterized as the Anthropocene epoch, much attention has been paid to heavy metal contamination with dust particles in many parts of the world [1,2]. Dust chemicals vary from elemental wastes to organic and inorganic compounds. Natural and anthropogenic heavy metals comprise the most important part of the dusts' inorganic components [3,4]. Disproportionate accumulation of heavy metals is a serious threat to living organisms. They pollute the natural environment and enact toxic impacts on living humans. Some heavy metals are essential for life; however, it must be taken into consideration that at higher levels, they can also impose some toxicological risk $[4,6]$. When studying urban atmospheric pollution, identification of source and location of the dust stands out as a high priority [7]. Hence, such studies should determine origin, distribution, environmental damage and health effects of the concerned heavy metals [8]. Dust storms with their important impacts on human health have turned into a frequent phenomenon of Iran's weather system. Their adverse effects on humans causing respiratory and cardiovascular diseases, and infections, in one hand, and on the environment, reducing visibility, creating agricultural losses, affecting the industry, and making satellite imagery complications are well-known [9]. On global scale, most of the dust particles come from arid and semiarid areas [10]. Recently, the amount of dust particles coming to Iran from Arabian countries has been dramatically increasing. They have viciously affected western and even central parts of Iran [11].

They are an important way of exposing people to heavy metals. In recent years, the large amounts of atmospheric dust particles have been depositing in many cities, crossing the western borders of Iran. The most dominant winds of the country blow from west to east. Therefore, as sources of Iran's dust storms; mainly 
western adjacent countries must be blamed for [12]. Saeedi et al. reported that although there is no confirmed origin, it is suspected that most of the dust particles originate from the dry wetlands of south eastern Iraq and the desserts of Iran's western neighbors [13]. The growth of population, industrial activities, and vehicles in large cities are the other major causes of pollution in urban environments. Road dust particle play as the leading path in terms of subjecting people to the toxic elements [14]. Cities have become source points of toxic chemicals from the unrestrained use of fossil fuels. Urban people are the most affected and the traffic policemen are the worst sufferers, because they are particularly close to the fumes of automobile exhaust [15]. The complexity of dust particles makes their characterization and source identification difficult [16]. Dust particles could be introduced as an indicator of heavy metal contamination from atmospheric deposition [17-20]. The close association of heavy metals with dust particles may be enhanced in the presence of anthropogenic sources of heavy metals. Depending on the population and economical activities, the level of contamination in a city varies from place to place. The presence of heavy metals in high concentrations in the environment lead to health hazards such as its adverse effects on the nervous, blood forming, renal, and reproductive systems. The toxicity of elements such as $\mathrm{Cu}, \mathrm{Cd}$, and $\mathrm{Zn}$, have been identified as being able to alter the purpose of the human central nervous and respiratory system, while also disturbing the endocrine [21].

Others include reduced intelligence, attention deficit, and behavioral abnormality, as well as increased cardiovascular diseases in adults [22]. Dust particles may also cause other kind of problems such as reduced soil fertility, damage to crops and reduced solar radiation [23]. While there are many published studies on the concentration of heavy metals in street dust of major cities in the developed countries; few research projects have been conducted addressing the issue in smaller cities of developing countries. Therefore, contamination and spatial distribution of heavy metals associated with street dust particles has become a major environmental issue in many western cities of Iran including Hamedan. The main objective of this study; therefore, was to determine the concentration of heavy metals $(\mathrm{Zn}, \mathrm{Cu}, \mathrm{Pb}, \mathrm{Mn}, \mathrm{Cr}$ and $\mathrm{Co}$ ) in street dust samples collected from different parts of Hamedan city; and then examine their spatial distribution.

\section{Materials and Methods}

\section{Study Area}

Hamedan province $\left(23^{\circ} 59^{\prime}\right.$ to $25^{\circ} 45^{\prime} \mathrm{N}$ and $47^{\circ} 34^{\prime}$ to $49^{\circ}$ $36^{\prime} \mathrm{E}$ ) is located on the west of Iran, with surface area of $70 \mathrm{~km} 2$ and urban population of 548378 based on the 2011 census. The sampling points were determined using a GPS. In total, 60 samples of dust particles were collected from urban locations in Hamedan city with 5 different traffic characteristics including heavy and low traffic density, industrial areas, residential districts, parks and the background. The background sample is an undisturbed soil that is representative of the genetic characteristics of soils of that region. The sampling points are marked on the map shown in Figure 1.

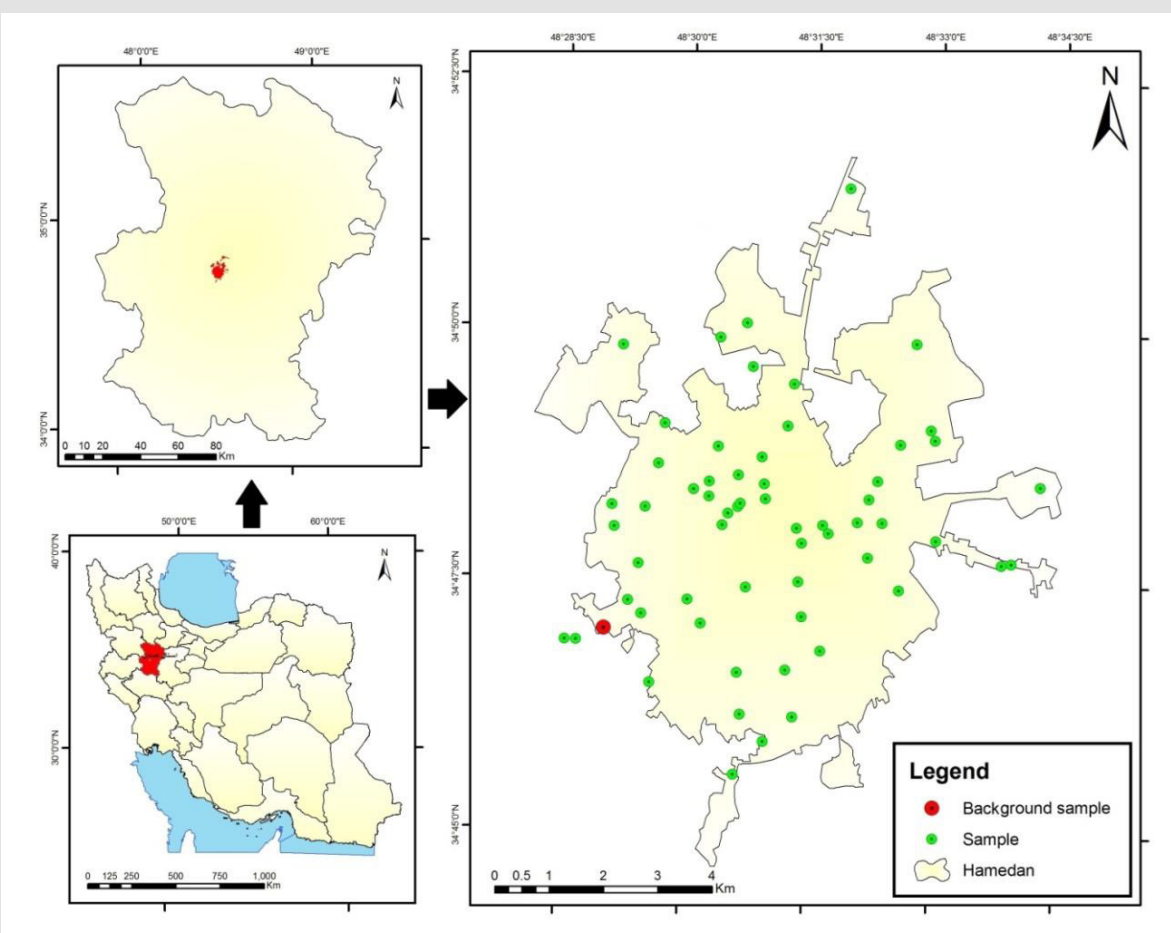

Figure 1: Location Map of the Studied Area Indicating Sampling Points in Hamedan City, Iran 


\section{Sample Collection}

The street dust samples were collected and placed into polyethylene bags using a clean brush and dustpan. The sampling was conducted in May (prior to rainy season) to avoid heavy metals being washed out by rain. Each street dust sample was 300-700 $\mathrm{g}$ in mass and collected from a $1 \mathrm{~m} 2$ area which measured by a ruler. Then, the samples were transferred to soil science laboratory of Bu-Ali Sina university, Hamedan, Iran; and were dried at room temperature for 3 days. Later, they were sieved through a $1 \mathrm{~mm}$ stainless steel sieve.

\section{Dust Analysis}

At first, 0.6 grams from every sample was digested [24] with a mixture of perchloric, nitric, and sulfuric acid in proportion of 1:5:1 and heated at $215^{\circ} \mathrm{C}$ until white fumes given off and a creamy color appeared. Then, $10 \mathrm{ml}$ deionized water was added into each sample and heated at $100^{\circ} \mathrm{C}$ for 1 hour. The solutions were allowed to cool, then filtered and made up to $100 \mathrm{ml}$. Finally, the concentrations of $\mathrm{Zn}, \mathrm{Cu}, \mathrm{Pb}, \mathrm{Mn}, \mathrm{Cr}$, and $\mathrm{Co}$ were determined using the atomic absorption spectrophotometric technique.

\section{Contamination Assessment Methods}

A number of calculation methods have been put forward for quantifying the degree of metal enrichment or pollution in dust particles [25]. In this study, geo-accumulation index ( $\left.\mathrm{I}_{\text {geo }}\right)$, enrichment factor (EF), and pollution index (PI) were calculated to assess the heavy metal contamination level in the road dust particles. However, the geo-accumulation index was originally used with bottom sediments [25]. It is also widely used to determine the pollution degree of heavy metals in dust particles and soil [26]. $\mathrm{I}_{\text {geo }}$ is computed by the following equation (eq. 1):

$$
\mathrm{I}_{\text {geo }}=\log 2[\mathrm{Cn} / 1.5 \mathrm{Bn}] \quad \text { eq. } 1
$$

Where $\mathrm{Cn}$ represents measured concentration of the element $\mathrm{n}$ in sampled street dust and $\mathrm{Bn}$ is geochemical background value of the element $\mathrm{n}$ in background sample. The geo-accumulation index is classified as shown in Table 1. The enrichment factor (EF) is used in studied samples to determine degree of metal contamination [27]. It was based on standardization of a determined element against a reference element. A reference element is often the one characterized by low occurrence variability such as $\mathrm{Fe}, \mathrm{Al}, \mathrm{Ti}, \mathrm{Mn}$, Sc, etc. [28-30]. The EF calculation is expressed below as eq.2:

Table 1: Standard of Contamination Degree by Geo-Accumulation Index.

\begin{tabular}{|c|c|c|}
\hline The Value of the Pollution Level & Class & I \\
\hline Unpolluted & 0 & $\mathrm{I}_{\text {geo }} \leq 0$ \\
\hline Unpolluted to moderately polluted & 1 & $0<\mathrm{I}_{\text {geo }}<1$ \\
\hline Moderately polluted & $2<\mathrm{I}_{\text {geo }}<2$ & $2<\mathrm{I}_{\text {geo }}<3$ \\
\hline Moderately to strongly polluted & $3<\mathrm{I}_{\text {geo }}<4$ \\
\hline Strongly polluted & $4<\mathrm{I}_{\text {geo }} \leq 5$ \\
\hline Strongly to extremely polluted & $6<\mathrm{I}_{\text {geo }}$ & 6 \\
\hline
\end{tabular}

$\mathrm{EF}=\mid \mathrm{Cn}($ sample $) /$ Cref(sample) $|/|$ Bn(background) $/$ Bref (background)| eq.2

Where $\mathrm{Cn}$ demonstrates concentration of the examined element in the dust sample; Bn stands for examined element for the background value; Cref shows content of reference element for normalization of the dust sample; and Bref delineates content of reference element for normalization of the background. Therefore, in this paper, the Mn was chosen as the reference element. Five Table 2: Contamination Categories Based on EF Values. categories of pollution are shown as the following (Table 2). The Pollution index (PI) was used to assess pollution degree and environment quality in this study.

The PI is defined as eq.3:

$\mathrm{PI}=\mathrm{Cn} / \mathrm{Cref}$ eq. 3

Where $\mathrm{Cn}$ and Cref stand for the concentration of examined element and the reference value, respectively (Table 3).

\begin{tabular}{|c|c|}
\hline EF & Contamination Category \\
\hline$<2$ & Deficiency to minimal enrichment \\
\hline $2-5$ & Moderate enrichment \\
\hline $5-20$ & Significant enrichment \\
\hline $20-40$ & Very high enrichment \\
\hline$>40$ & Extremely high enrichment \\
\hline
\end{tabular}


Table 3: Classification of PI Values.

\begin{tabular}{|c|c|c|}
\hline Pollution Level & Class & PI \\
\hline Unpolluted & 1 & PI $\leq 1$ \\
\hline Low polluted & 2 & $1<$ PI $\leq 2$ \\
\hline Moderately polluted & $3<$ PI $\leq 3$ & $3<$ PI \\
\hline Strongly polluted & 4 & \\
\hline
\end{tabular}

\section{Methods of Mapping Heavy Metal Concentrations}

The spatial distribution maps of heavy metal concentrations were generated through the Inverse Distance Weighted (IDW) interpolating data from 60 street dust samples using Arc map software.

\section{Results and Discussion}

\section{Heavy Metal Concentration}

Concentrations of $\mathrm{Zn}, \mathrm{Cu}, \mathrm{Pb}, \mathrm{Mn}, \mathrm{Cr}$, and Co were measured in all 60 street dust samples. Minimum and maximum concentrations, mean values, and standard deviations for each analyzed heavy metal as well as corresponding background values of the metals are presented in Table 4. The $\mathrm{Zn}$ concentration in the samples ranged from $85.7-333.3 \mathrm{mg} \mathrm{kg}^{-1}$ with an average concentration of $189.9 \mathrm{mg} \mathrm{kg}^{-1}$, which was higher than the average $\mathrm{Zn}$ concentration

in the background (162.4 $\mathrm{mg} \mathrm{kg}^{-1}$ ). The highest values of $\mathrm{Zn}$ were found in the heavy traffic and industrial areas, indicating that the Zn most commonly was coming from those locations. Faiz et al. also recorded that the concentration of $\mathrm{Zn}$, compared to all of other studied elements, was manifested to be the highest. The average concentration of $\mathrm{Cu}$ in the street dust samples from Hamedan city was $63.8 \mathrm{mg} \mathrm{kg}^{-1}$ with a range of $21.3-261.9 \mathrm{mg} \mathrm{kg}^{-1}$ (Table 4). The average concentration was greater than the background $(15.16 \mathrm{mg}$ $\mathrm{kg}^{-1}$ ). Industrial areas and parks, with the average of 86.7 and 49.3 $\mathrm{mg} \mathrm{kg}^{-1}$,contained the highest and lowest content of copper in the studied area, respectively. Copper is an essential trace element that is widely distributed in the environment. Elemental $\mathrm{Cu}$ does not break down in the environment. The $\mathrm{Cu}$ can be found in plants and animals, in many foods and beverages, including drinking water [31].

Table 4: Heavy Metal Concentrations $\left(\mathrm{mg} \mathrm{kg}^{-1}\right)$ in Dust Particles Collected from Hamedan City.

\begin{tabular}{|c|c|c|c|c|c|c|c|}
\hline \multicolumn{2}{|c|}{ Sampling Location } & $\mathbf{Z n}$ & $\mathrm{Cu}$ & $\mathbf{P b}$ & Mn & $\mathrm{Cr}$ & Co \\
\hline \multirow{4}{*}{ Heavy Traffic } & maximum & 325.9 & 199.9 & 123.3 & 700.2 & 65.4 & 39.6 \\
\hline & minimum & 130.3 & 21.2 & 48.5 & 257.4 & 13.9 & 5.5 \\
\hline & mean & 216.9 & 64.9 & 64.4 & 384.7 & 33.4 & 21 \\
\hline & SD & 0.2 & 0.6 & 0.3 & 0.2 & 0.4 & 0.4 \\
\hline \multirow{4}{*}{ Low Traffic } & maximum & 325 & 261.9 & 117.8 & 513.9 & 53.1 & 29.4 \\
\hline & minimum & 85.7 & 23.1 & 30.8 & 248 & 8.1 & 2.3 \\
\hline & mean & 178.7 & 70.3 & 60.2 & 361.7 & 27 & 16.8 \\
\hline & SD & 0.4 & 0.9 & 0.4 & 0.2 & 0.4 & 0.4 \\
\hline \multirow{4}{*}{ Parks } & maximum & 183.2 & 148.1 & 66.4 & 572 & 57.3 & 31.9 \\
\hline & minimum & 108.3 & 24.1 & 42.9 & 247.2 & 8 & 6.1 \\
\hline & mean & 142.9 & 49.3 & 51.5 & 394.9 & 36 & 21.4 \\
\hline & SD & 0.1 & 0.7 & 0.6 & 0.2 & 0.4 & 0.3 \\
\hline \multirow{4}{*}{ Residential } & maximum & 331.3 & 105.7 & 65.4 & 469.3 & 53.8 & 25.2 \\
\hline & minimum & 87.9 & 27.2 & 38.8 & 230.5 & 8.2 & 2.5 \\
\hline & mean & 167.3 & 55.5 & 50.6 & 369 & 30.7 & 21.6 \\
\hline & SD & 0.4 & 0.5 & 0.2 & 0.2 & 0.5 & 0.5 \\
\hline \multirow{4}{*}{ Industrial } & maximum & 333.3 & 194.3 & 161.5 & 484.2 & 58.3 & 25.9 \\
\hline & minimum & 212.5 & 42.3 & 42.9 & 269.7 & 10.1 & 10.7 \\
\hline & mean & 289.9 & 86.7 & 91.1 & 388.3 & 38.7 & 20.3 \\
\hline & SD & 0.1 & 0.6 & 0.4 & 0.2 & 0.4 & 0.3 \\
\hline \multicolumn{2}{|c|}{ Background } & 162.4 & 15.16 & 55.25 & 390.5 & 69.8 & 44.4 \\
\hline
\end{tabular}

Shi and Wang reported that in their studied area, mean content of $\mathrm{Cu}$ particles was found to be almost 6 times higher than the background. Lu found the maximums $\mathrm{Cu}$ in the samples from heavy traffic sites, while their minimums were detected in dust samples from residential site with less traffic density. The source of $\mathrm{Cu}$ and $\mathrm{Zn}$ in street/road dust has been shown to be tire abrasion, 
corrosion of metallic parts of cars, lubricants leakage, industrial and incinerator emissions [32]. The $\mathrm{Pb}$ concentration of the dust samples fluctuated from 30.8-161.5 mg kg-1 with an average concentration of $63 \mathrm{mg} \mathrm{kg}^{-1}$, which was higher than the background average ( $55.25 \mathrm{mg} \mathrm{kg}^{-1}$ ). The highest levels of $\mathrm{Pb}$ were found in the industrial locations showing them as the most important sources of $\mathrm{Pb}$ in Hamedan city. It is believed that $\mathrm{Pb}$ is responsible for many negative effects on human bodies such as damaging kidneys, the nervous, and reproductive systems. It is also the element of most concern in environmental heavy metal pollution studies [32]. Wei et al. further observed that areas of high traffic density were associated with the highest levels of $\mathrm{Pb}$.

The Mn concentration in the samples ranged from 230.5-700.2 $\mathrm{mg} \mathrm{kg}{ }^{-1}$ with an average concentration of $378.5 \mathrm{mg} \mathrm{kg}^{-1}$, which was very close to $\mathrm{Mn}$ concentration in the background sample $(390.5$ $\mathrm{mg} \mathrm{kg}^{-1}$ ). Many studies have manifested that raised concentration of $\mathrm{Mn}$ in road dusts were as a result of natural sources [33]. So, almost similar levels of $\mathrm{Mn}$ in the samples of different locations could endorsed that concentration of this metal in street dust from Hamedan city was influenced by natural sources. The average concentration of $\mathrm{Cr}$ in the street dust samples varied from 8-65.4 mg kg-1 with an average of $33 \mathrm{mg} \mathrm{kg}^{-1}$ (Table 4). The average concentration of $\mathrm{Cr}$ in dust samples was very much lower than the background sample (69.8 $\left.\mathrm{mg} \mathrm{kg}^{-1}\right)$. The low levels of $\mathrm{Cr}$ in dust samples could suggest that the $\mathrm{Cr}$ in dust particle was also influenced by natural sources.

The Co concentration in the dust samples reached from 2.3$39.6 \mathrm{mg} \mathrm{kg}^{-1}$ with an average concentration of $19.8 \mathrm{mg} \mathrm{kg}^{-1}$, which was very much lower than the Co concentration in the background sample (44.4 $\mathrm{mg} \mathrm{kg}^{-1}$ ). The low levels of Co in dust particle samples could imply that the Co was originated from natural sources. Findings showed that the mean concentrations of $\mathrm{Zn}, \mathrm{Cu}$ and $\mathrm{Pb}$, and $\mathrm{Cu}$ in particular, were much higher compared to their background values. This implied that such metals in dust particles from Hamedan city were impacted by anthropogenic sources. In contrast, the mean concentrations of $\mathrm{Mn}, \mathrm{Cr}$ and Co were lower compared to their background values; this revealed that so-called metals in street dust from Hamedan City were induced by natural sources. Concentarations of $\mathrm{As}, \mathrm{Cd}, \mathrm{Cu}, \mathrm{Ni}, \mathrm{Pb}$ and $\mathrm{Zn}$ in a similar study in China exceeded the background values [34].

\section{Spatial Distribution of Heavy Metals}

The spatial distribution of metal concentrations is a useful method to assess the possible sources of enrichment, and to identify hot-spot areas with highest metal concentration. According to Burgos et al this form of spatial pattern supports the theory of reduction of heavy metal pollution caused by fine dust particles moving from West to East. For these elements, Wei et al observed relatively high spatial variability. Their hot-spot areas were mainly associated with main roads where high traffic density was identified. Such features suggested that the metals were probably due to vehicular emissions [34]. Distribution patterns of the studied elements in the whole area of Hamedan are represented in Figure 2. Similar patterns of spatial distribution were observed for $\mathrm{Zn}, \mathrm{Pb}$, and $\mathrm{Cu}$. Their hot-spot areas were in North West and central parts of the city and mainly associated with industrial areas and main roads with high traffic density, which also suggested these metals, might be derived from industrial sources and vehicular emissions. The reason behind low concentrations of these metals in the West and South West areas of the city may be due to Abbas Abad mountains that act as a barrier against penetration of west winds. On the other hand, over population and high traffic density in central parts of city, could be blamed for high level of studied heavy metals in central parts of the city.

$\mathrm{Mn}, \mathrm{Cr}$, and Co also showed similar spatial distributions and had relatively high spatial variability. The mean concentration of $\mathrm{Mn}$ was very close to its background concentration while $\mathrm{Cr}$ and Co levels were lower than their backgrounds. These findings indicated that these three metals may not have been originated from anthropogenic sources. So, concentrations of $\mathrm{Mn} \mathrm{Cr}$, and Co in street dust samples are mainly attributed to natural sources. While it is theorized that heavy metal pollution reduces while fine dusts move from West to East, findings on these three heavy metals did not endorse this theory of reduction of heavy metal pollution. Levels of heavy metals found in the studied areas proved that sources of Mn, $\mathrm{Cr}$ and Co were natural and not anthropogenic.

\section{Assessment of Pollution Level}

$\mathbf{I}_{\text {geo }}$ of Heavy Metals: The calculated results of heavy metals' $I_{\text {geo }}$ of Hamedan street dusts are presented in Table 5. The $\mathrm{I}_{\text {geo }}$ values for $\mathrm{Zn}, \mathrm{Cu}, \mathrm{Pb}, \mathrm{Mn}, \mathrm{Cr}$, and Co ranged from -0.8 to $0.2,0.9$ to $2.3,-0.7$ to $0,-0.7$ to $-0.6,-2.1$ to -1.6 , and -2.3 to -1.7 ; respectively, and with a mean value of $-0.4,1.4,-0.4,-0.6,-1.8$, and -1.9 . The mean values of $\mathrm{I}_{\text {geo }}$ decreased in the order of $\mathrm{Cu}>\mathrm{Pb}, \mathrm{Zn}>\mathrm{Mn}>\mathrm{Cr}>\mathrm{Co}$. The mean $\mathrm{I}_{\text {geo }}$ of $\mathrm{Zn}, \mathrm{Pb}, \mathrm{Cr}$ and $\mathrm{Co}$ were lower than zero-i.e unpolluted; while $\mathrm{Cu}$ with its mean $\mathrm{I}_{\text {geo }}$ ranging from 1 to 2 , was classified as moderately polluted. The highest values of $\mathrm{I}_{\text {geo }}$ were observed in industrial areas followed by areas with heavy traffic density. In a similar study, Wei et al concluded that the main mean $\mathrm{I}_{\text {geo }}$ values ranged from 0 to 1 with $\mathrm{Cr}$ and $\mathrm{Co}$ as exceptions where their Igeo values were less than 0 , indicating that road dust in the studied area was between uncontaminated and contaminated. A particularly high $\mathrm{I}_{\text {geo }}$ value for $\mathrm{Cu}$ at 2.3 suggested that the $\mathrm{Cu}$ in street dust samples were most notably affected by anthropogenic sources, originating primarily from traffic and industrial activities.

Enrichment Factor of Heavy Metals: The EF results from Hamedan street dusts are shown in table 5. The Mn was chosen as reference element in the studied areas. Frequently, $\mathrm{Fe}, \mathrm{Al}$, Li, and $\mathrm{Mn}$ are also used as reference metals. As an alternative, any other metal found to have little to no anthropogenic sources in the area may 
be used [35]. The EFs of $\mathrm{Zn}, \mathrm{Cu}, \mathrm{Pb}, \mathrm{Cr}$, and Co varied from 0.9-1.8, 2.3-5.8, 1-1.3, 0.4-0.5, and 0.4-0.5; correspondingly, with an average of $1.3,4.4,1.3,0.5$, and 0.5 . Shi and Wang who used Mn as the reference element found $\mathrm{Cu}$ as the most polluted element in road dust particles (Table 6). The order of EF values was as the following: $\mathrm{Cu}>\mathrm{Zn}, \mathrm{Pb}>\mathrm{Cr}$, Co, similar to the $\mathrm{I}_{\text {geo }}$ order, which could also be interpreted as decreasing order of their overall contamination of street dusts from Hamedan city. The anthropogenic pollution is clearly identified when the maximum EF of each heavy metal is larger than 3. The mean EF of $\mathrm{Cu}$ was higher than 2, while the mean $\mathrm{EF}$ of $\mathrm{Zn}, \mathrm{Pb}, \mathrm{Cr}$, and Co were less than 2. These findings showed that $\mathrm{Cu}$ in street dusts of Hamedan city was the main pollutant, and largely originated from anthropogenic sources.
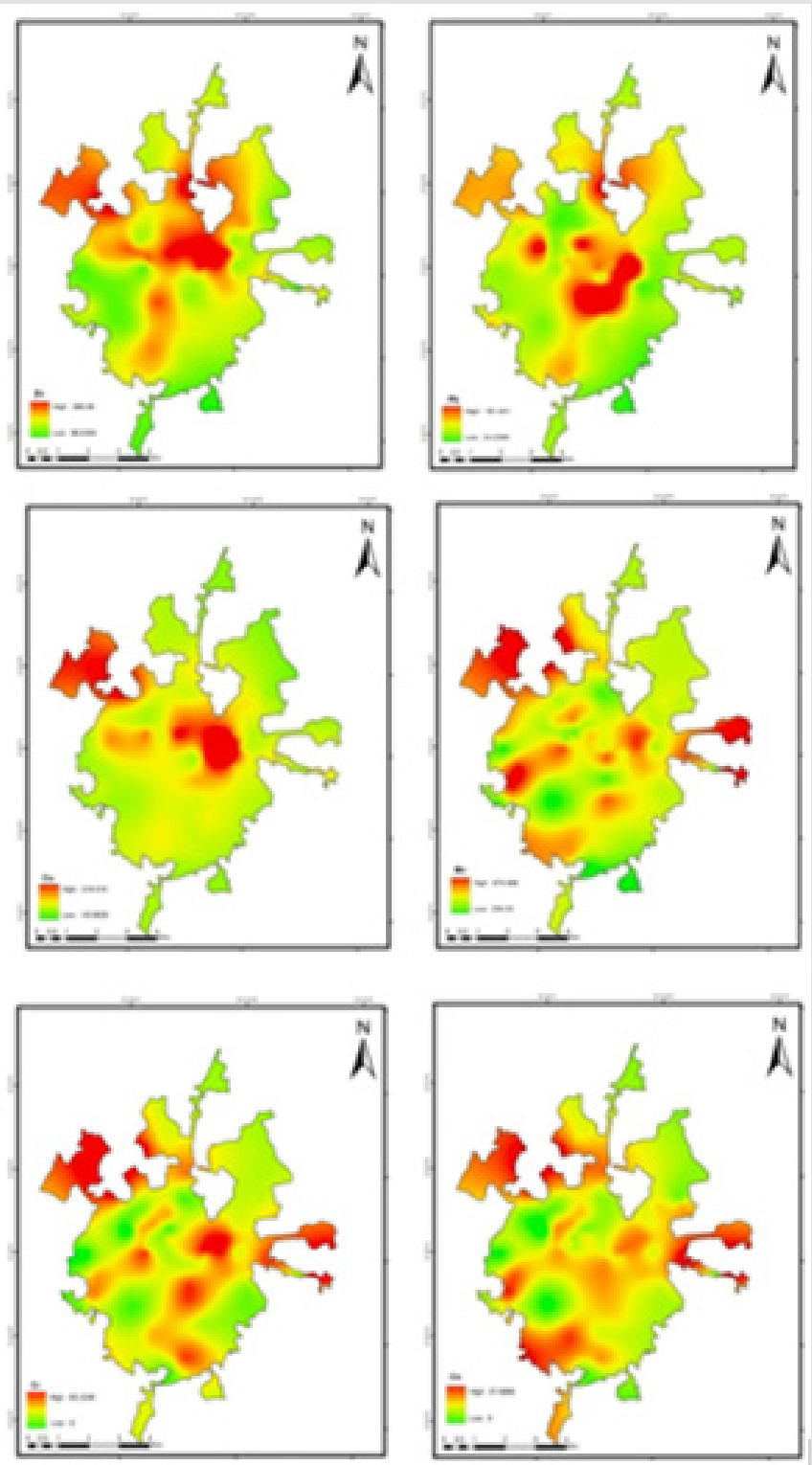

Figure 2: Spatial Distribution of the Concentrations of Heavy Metals in Hamedan.

Table 5: $\mathrm{I}_{\text {geo }}$ for Heavy Metals in Street Dusts of Hamedan City.

\begin{tabular}{|c|c|c|c|c|c|c|}
\hline \multirow{2}{*}{$\begin{array}{c}\text { Sampling } \\
\text { Location }\end{array}$} & $\mathbf{7 n}$ & $\mathbf{C u}$ & $\mathbf{P b}$ & $\mathbf{M n}$ & \multicolumn{2}{c|}{ Igeo Values } \\
\hline Heavy Traffic & -0.2 & 1.3 & -0.4 & -0.6 & -1.8 & $\mathbf{C o}$ \\
\hline Low Traffic & -0.5 & 1.2 & -0.5 & -0.7 & -2.1 & -2.8 \\
\hline Parks & -0.8 & 0.9 & -0.5 & -0.6 & -1.7 & -1.7 \\
\hline Residential & -0.7 & 1.1 & -0.7 & -0.7 & -2 & -2.3 \\
\hline Industrial & 0.2 & 2.3 & 0 & -0.6 & -1.6 & -1.7 \\
\hline
\end{tabular}


Table 6: EF for Heavy Metals in Street Dusts of Hamedan City.

\begin{tabular}{|c|c|c|c|c|c|}
\hline \multirow{2}{*}{ Sampling Location } & \multicolumn{5}{|c|}{ EF Values } \\
\hline & $\mathbf{Z n}$ & $\mathrm{Cu}$ & $\mathbf{P b}$ & $\mathrm{Cr}$ & Co \\
\hline Heavy Traffic & 1.4 & 4.4 & 1.3 & 0.5 & 0.5 \\
\hline Low Traffic & 1.2 & 4.9 & 1.2 & 0.4 & 0.4 \\
\hline Parks & 0.9 & 3.2 & 1.2 & 0.5 & 0.5 \\
\hline Residential & 1.1 & 3.7 & 1 & 0.4 & 0.4 \\
\hline Industrial & 1.8 & 5.8 & 1.6 & 0.5 & 0.5 \\
\hline
\end{tabular}

Pollution Index of Heavy Metals: The PI of $\mathrm{Zn}, \mathrm{Cu}, \mathrm{Pb}, \mathrm{Mn}$, $\mathrm{Cr}$, and Co fluctuated from 0.9-1.8, 3.2-5.7, 0.9-1.6, 0.9-1, 0.4-0.6, and $0.4-0.5$, with the mean values of $1.2,4.3,1.1,1,0.5$, and 0.5 , respectively. The order of PI values was: $\mathrm{Cu}>\mathrm{Zn}>\mathrm{Pb}>\mathrm{Mn}>\mathrm{Cr}$, Co .According to the PI values, at first, $\mathrm{Mn}, \mathrm{Cr}$, and Co were classified as unpolluted. Then, $\mathrm{Zn}$ and $\mathrm{Pb}$ were labeled as low polluted. Finally,

Table 7: PI Values of Heavy Metals in Street Dusts of Hamedan City.

\begin{tabular}{|c|c|c|c|c|c|c|}
\hline \multirow{2}{*}{$\begin{array}{l}\text { Sampling } \\
\text { Location }\end{array}$} & \multicolumn{6}{|c|}{ PI Values } \\
\hline & $\mathrm{Zn}$ & $\mathrm{Cu}$ & $\mathbf{P b}$ & Mn & $\mathrm{Cr}$ & Co \\
\hline Heavy Traffic & 1.3 & 4.3 & 1.1 & 1 & 0.5 & 0.5 \\
\hline Low Traffic & 1.1 & 4.6 & 1 & 0.9 & 0.4 & 0.4 \\
\hline Parks & 0.9 & 3.2 & 1 & 1 & 0.5 & 0.5 \\
\hline Residential & 1 & 3.6 & 0.9 & 0.9 & 0.4 & 0.4 \\
\hline Industrial & 1.8 & 5.7 & 1.6 & 1 & 0.6 & 0.5 \\
\hline
\end{tabular}

\section{Conclusion}

The concentrations and contamination levels of $\mathrm{Zn}, \mathrm{Cu}, \mathrm{Pb}, \mathrm{Mn}$, $\mathrm{Cr}$, and Co were studied in street dust collected from Hamedan city, Iran with three contamination assessment methods. The mean values for $\mathrm{Zn}, \mathrm{Cu}, \mathrm{Pb}, \mathrm{Mn}, \mathrm{Cr}$, and $\mathrm{Co}$ in the dust samples were 189.9, $63.8,63,378.5,33$, and $19.8 \mathrm{mg} \mathrm{Kg}^{-1}$ respectively. Results showed that the mean concentrations of $\mathrm{Zn}, \mathrm{Cu}$ and $\mathrm{Pb}$ were much higher than their background values. In contrast, the mean concentrations of $\mathrm{Mn}, \mathrm{Cr}$ and Co were lower compared to their background values. Similar patterns of spatial distribution were observed for $\mathrm{Zn}, \mathrm{Pb}$ and $\mathrm{Cu}$. Their hot-spot areas were in North West and central parts of the city, while $\mathrm{Mn}, \mathrm{Cr}$ and Co also showed similar spatial distributions and had relatively high spatial variability. The values of $\mathrm{I}_{\text {geo }}$ were in the following order: $\mathrm{Cu}>\mathrm{Pb}, \mathrm{Zn}>\mathrm{Mn}>\mathrm{Cr}>\mathrm{Co}$. The results of $\mathrm{I}_{\text {geo }}$ showed that dust particles in Hamedan city were uncontaminated regarding $\mathrm{Zn}, \mathrm{Pb}, \mathrm{Mn}, \mathrm{Cr}$, and $\mathrm{Co}$; however moderately contaminated with $\mathrm{Cu}$. Except for $\mathrm{Cu}$, the order for some other elements is in harmony with findings. The values of EF were in the following order: $\mathrm{Cu}>\mathrm{Zn}, \mathrm{Pb}>\mathrm{Cr}$, Co. The EF values showed that dust particles in Hamedan city were uncontaminated regarding $\mathrm{Zn}, \mathrm{Pb}, \mathrm{Cr}$, and $\mathrm{Co}$ the following order: $\mathrm{Cu}>\mathrm{Zn}>\mathrm{Pb}>\mathrm{Mn}>\mathrm{Cr}$, Co. These values of PI showed that dust particles in Hamedan city were uncontaminated regarding $\mathrm{Mn}, \mathrm{Cr}$, and $\mathrm{Co}$, nevertheless moderately contaminated with $\mathrm{Zn}$ and $\mathrm{Pb}$ and of course contaminated with $\mathrm{Cu}$. while moderately contaminated with $\mathrm{Cu}$. The values of PI were in
Cu was found to be strongly polluted with highest level of pollution in the studied area. Faiz et al. discovered similar results illustrating that the overall pollution levels for all the elements, while employing this parameter, were correlated to the middle level except for the $\mathrm{Cu}$ that was found to be in the high-level range (Table 7).
The high values of $\mathrm{I}_{\text {geo }}, \mathrm{EF}$ and PI for $\mathrm{Cu}$ in the sampled street dusts indicated that there was a considerable $\mathrm{Cu}$ pollution, which mainly originated from traffic and industry activities. The $\mathrm{I}_{\text {geo }}, \mathrm{EF}$ and PI of other studied heavy metals were low and revealed low levels of these heavy metals' pollution in street dusts from studied area. These findings stressed on the fact that more attention should be paid on heavy metal contamination in the street dusts of the city, especially on the $\mathrm{Cu}$. Some protective measures such as encouraging use of public transport; replacing liquid fossil fuels with gaseous fuel, and planting more green areas are suggested to combat the problem.

\section{References}

1. Al Khashman, OA (2004) Heavy metal distribution in dust, street dustand soils from the workplace in Karak Industrial Estate. Jordan Atmospheric Environment 38(39): 6803-6812.

2. Ashrafi KH, Shafiepour M, Aslemand A, Sarmad GH (2014) Dust storm simulation over Iran using HYSPLIT. Journal of Environmental Health Science and Engineering 336: 9-21.

3. Basart S, Vendrell L, Baldasano JM (2016) High-resolution dust modelling over complex terrains in West Asia. Aeolian Research 23: 37- 50.

4. Burgos P, Madejón M, Pérez de Mora A, Cabrera F (2008) Horizontal and vertical variability of soil properties in a trace element contaminated area. International Journal of Applied Earth Observation and Geoinformation 10(1): 11-25.

5. Charlesworth S, Everett M, McCarthy, R Ordonez, A De Miguell (2003) A comparative study of heavy metal concentration and distribution in deposited street dusts in a large and a small urban area: Birmingham 
and Coventry, West Midlands, UK. Environment International 29(5): 563-573.

6. Christoforidis A, Stamatis N (2009) Heavy metal contamination in street dust and roadside soil along the major national road in Kavala's region, Greece. Geoderma 151(3-4): 257-263.

7. Faiz A, Tufail M, TayyebJaved M, Chaudhry MM, Siddique N (2009) Road dust pollution of $\mathrm{Cd}, \mathrm{Cu}, \mathrm{Ni}, \mathrm{Pb}$ and $\mathrm{Zn}$ along Islamabad Expressway, Pakistan. Microchemical Journal 92(2): 186-192.

8. Ferreira Baptista L, Miguel E De (2005) Geochemistry and risk assessment of street dustin Luanda, Angola: a tropical urban environment. Atmospheric Environment 39: 4501-4512.

9. Gerivani H, Lashkaripour G, Ghafoori M, Jalali N (2011) The source of dust storm in Iran: a case study based on geological information and rainfall data. Carpathian Journal of Earth and Environmental Sciences, 6(1): 297-308.

10. Gordeev VV, Rachold V, Vlasova IE (2004) Geochemical behavior of major and trace elements in suspended particulate material of the Irtysh River, the main tributary of the OB River, Siberia. Applied Geochemistry 19(4): 593-610.

11. Han X, Lu X, Zhang Q, Hai Q, Pan H (2016) Grain-size distribution and contamination characteristics of heavy metal in street dust of Baotou, China. Environmental Earth Sciences 75(6): 1-10.

12. Han YM, Du PX, Cao JJ, Posmentier ES (2006) Multivariate analysisof heavy metal contamination in urban dusts of Xian, Central China. Science of the total environment 355(1-3): 176-186

13. Hojati S, Khademi H, Faz Cano A, Landi A (2012) Characteristics of dust deposited along a transect between central Iran and the Zagros Mountains. Catena 88(1): 27-36.

14. Jiries AG, Hussein $\mathrm{HH}$, Halaseh $\mathrm{Z}$ (2001) The quality of water and sediments of street runoff in Amman, Jordan. Hydrological Process 15(5): 815-824.

15. Li X, Zhang S, Yang M (2014) Accumulation and risk assessment of heavy metals in dust in main living areas of Guiyang City, Southwest China Chinese Journal of Geochemistry. 33: 272-276.

16. Li J, Lu Y, Yin W, Gan H, Zhang C (2009) Distribution of heavy metals in agricultural soils near a petrochemical complex in Guangzhou, China. Environmental monitoring and assessment 153: 365-375.

17. Lu X, Wang L, Li LY, Lei K, Huang L (2010) Multivariate statistical analysis of heavy metals in street dust of Baoji, NW China. Journal of Hazardous Materials. 173(1-3): 744-749.

18. Lu X, Wang L, Lei K, Huang J, Zhai Y (2008) Contamination assessment of copper, lead, zinc, manganese and nickel in street dust of Baoji, NW China. Journal of Hazardous Materials 161(2-3): 1058-1062.

19. Maa, Singhirunnusorn W (2012) Distribution and Health Risk assessment of heavy metals in surface dusts of MahaSarakham municipality. Procedia social and behavioral sciences 50: 280-293.

20. Mafuyai GM, Kamoh NM, Kangpe NS, Ayuba SM, Eneji IS (2015) Heavy metals contamination in roadside dust along major traffic roads in Jos

\section{ISSN: 2574-1241}

DOI: $10.26717 /$ BJSTR.2020.30.004882

Ghasem Rahimi . Biomed J Sci \& Tech Res

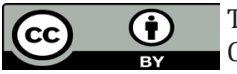

This work is licensed under Creative Commons Attribution 4.0 License

Submission Link: https://biomedres.us/submit-manuscript.php metropolitan area, Nigeria. Journal of Environment and Earth Science 5(5): 48-57.

21. Mafuyai GM, Eneji IS, Shaato R (2014) Concentration of Heavy Metals in Respirable Dust in Jos Metropolitan Area, Nigeria. Open Journal of Air Pollution 3(1): 10-19.

22. Meena M, Meena BS, Chandrawat U, Rani A (2014) Seasonal Variations and Sources of Heavy Metals in Free Fall Dust in an Industrial City of Western India. Iranica Journal of Energy \& Environment 5(2): 160-166.

23. Norouzi S, Khademi H (2015) Source identification of heavy metals in atmospheric dust using platanusorientalis L. leaves as bioindicator Eurasian Journal of Soil Science 4(3): 144-152.

24. Norouzi S, Khademi H, Cano AF, Acosta JA (2016) Biomagnetic monitoring of heavy metals contamination in deposited atmospheric dust, a case study from Isfahan, Iran. Journal of Environmental Management 173: 55-64.

25. Raj SHP, Neena K, Bir Singh SK, Kumari WK, Mahesh SH (2014) Determination of Heavy metals in Street Dust from Different Types of Land Use of Kathmandu Valley, Nepal. Research journal of chemical sciences 4(7): 82-92.

26. Reimann C, Caritat P (2000) Intrinsic flaws of element enrichment factors (EFs) in environmental geochemistry. International journal of energy and environment 34: 5084-5091.

27. Rezazadeh M, Irannejad P, Shao Y (2013) Climatology of the Middle East dust events. Aeolian Research. 10: 103-109.

28. Saeedi M, Li LY, Salmanzadeh M (2012) Heavy metals and polycyclic aromatic hydrocarbons: Pollution and ecological risk assessment in street dust of Tehran. Journal of Hazardous Materials 9: 227-228.

29. Sammut ML, Noack Y, Rose J, Hazemann JL, Proux O (2010) Speciation of $\mathrm{Cd}$ and $\mathrm{Pb}$ in dust emitted from sinter plant. Chemosphere 78: 445-450.

30. Sezgin N, Ozcan HK, Demir G, Nemlioglu S, Bayat C (2003) Determination of heavy metal concentrations in street dusts in Istanbul E-5 highway. Environment International 29(7): 979-985.

31. Shao Y (2008) Physics and Modeling of Wind Erosion. Berlin of Germany, Springer Press pp. 172-174

32. Shi X, Wang J (2013) Comparison of different methods for assessing heavy metal contamination in street dust of Xianyang City, NW China. Environmental Earth Sciences 68(8): 2409-2415.

33. Tam NFY, Yao MWY (1998) Normalization and heavy metal contamination in Mangrove Sediments. Science of the Total Environment 216(1-2): 3339.

34. Wang X, Qin Y (2007) Some characteristics of the distribution of heavy metals in urban topsoil of Xuzhou, China. Environmental Geochemistry and Health 29: 11-19.

35. Wei B, Jiang F, Li X, Mu Sh (2009) Spatial distribution and contamination assessment of heavy metals in urban road dusts from Urumqi, NW China. Microchemical Journal 93(2): 147-152.

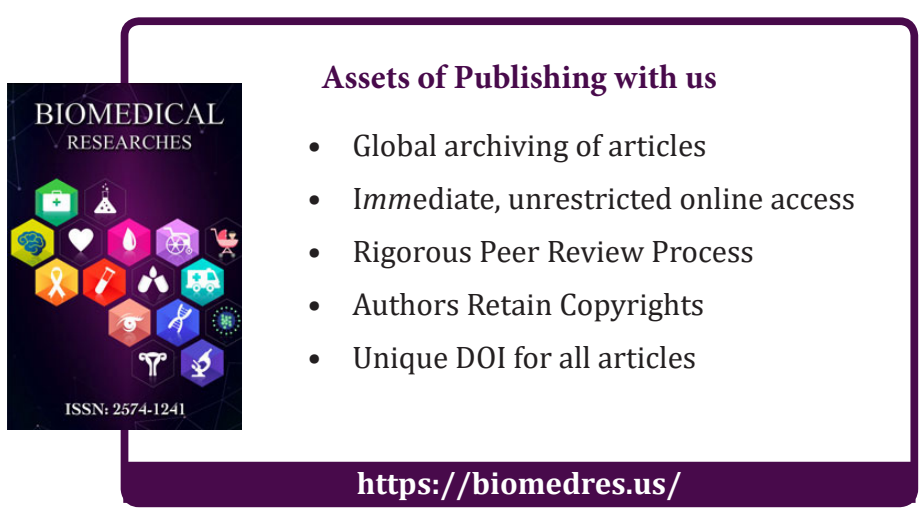

